\title{
Community Culture and Character: Correlational Study of Youth Offender in Child Prison
}

\author{
Dina Sukma ${ }^{1}$, Azwar Ananda ${ }^{2}$, Nurhizrah Gistituati ${ }^{3}$, Daharnis Daharnis ${ }^{4}$ \\ ${ }^{1234}$ Universitas Negeri Padang, Padang - Indonesia, (sukmadina@fip.unp.ac.id)
}

\begin{abstract}
Youth offenders were juvenile delinquency that offend the law and according to the decision of law they must live in child prison. However, this community culture maybe has influences the development of moral character of youth offender along live in child prisoner. This study were correlational study that tries to reveal the correlation of community culture and character of youth offender by using structured questionnaire about characteristic of 20 youth offender living in jail and School Culture Scale (SCS) to measure youth offender's perception about child prison's community culture. Result of this study shows that there relationship between youth offender's perception of community culture and youth offender character with Pearson correlation is 0,512 significant at 0,05 . Character building will be much easier to do in an environment where there good relationship of each other, democratic, responsible, and friendly values are perceived as prevailing values.
\end{abstract}

Keywords: Community Culture, Character, Youth Offender, Child Prison

\section{Introduction}

Human is "homo socious" that cannot be separated from their community. Every community build culture that bonding and guidance to their members by applying norms and rules. Members who doesn't obeying the norm or rules will face many social problem or even psychological problem such as depression, or other personality problem. Acceptance from their community makes the members feel being love and cares and live with full of happiness.

Every community has their own culture that named as community culture (Snarey and Samuelson, 2014). In school, it named as school culture that John Dewey formulated as hidden curriculum. According to School Culture Scale there is four aspect of school culture that has strong internal consistency there were: student relationship, student and teacher relationship, school norms, democratic and education opportunities (D'Allessandro and Ann Higgins, 1989).

John Dewey says that it will be useless if we try to build student character without considering school culture (Power and D'Alessandro, 2014). Student character will develop in positive school culture (Wren, 1999). So, if we implemented into child prison, positive community culture has influences character building of youth offender. Building character of student are easier if they live in environment that percept honesty, care, and tenderness as a norm (Lickona 2008). Hidden curriculum (school culture) were more effective to influences behavior and thinking pattern of all members 
school community. Piaget suggest democratic environment because democracy gave child intellectual liberty and moral development (Lickona 2008)

In child prison in West Sumatera Indonesia, the youth offender contains many adolescents that came from different places in West Sumatera Province. Four of 20 youth offender were recidivist. This means that there is no moral, character or behavioral changes. The child prison as guidance and educational institution didn't success to reach this goal.

As a "school" in another term, child prisons contain youth offender as the student, tutor as teacher, chief of child prison as head of the school, child prison rules or norm as school norms. According to School Culture Scale there is four aspect of school culture that has strong internal consistency there were: student relationship, student and teacher relationship, school norms, democratic and education opportunities ( $\mathrm{D}^{\prime}$ Allessandro dan Ann Higgins, 1989). If those aspects implement to child prison the aspect will be: youth offender relationship, youth offender and tutor relationship, norms, democratic and education opportunities.

Based on expert explanation about relationship of school culture and character, so there is question comes: how is relationship of school culture and character of youth offender in child prison in West Sumatera Province?

The rest of this article is organized as follows: Section 2 literature review and develop research hypotheses. Section 3 discuss data source and variable construction, Section 4 depicts method and report results. Section 5 conclude the paper with a discussion on contributions and limitations.

Culture is the hole thinking, value, moral and human belief that produce through human interaction with environment (Kemendiknas, 2010: 8). In school context, school culture is part of pattern behavior and the way to act that shaping automatically be part of live in a educational community (Doni Koesoema, 2015) Base pattern behavior and way to act is a social norm, school rule, and educational policy in local level. Those aspect shows in members when they think, made decision and act in daily live. School culture were important aspect that very important in character and culture building (Kemnediknas, 2012)

Meanwhile, Mahmud (2014) says that school culture are school live where student interaction each other, student and teacher, administration staff, and school counselor. The interaction were bonding by norms, moral, and etics that applying in that school. Leadership, modeling, tenderness, tolerance, hardworking, discipline, social cares, environment cares, nationality, responsible, and sense of belonging were values that determined school culture.

Base on expert definition, school culture were thinking pattern, attitude pattern and pattern of behavior that belonging to members of community as an institution in this case were child prison where shaping by interaction of head of child prison, youth offender, tutor, staff, that bounding by norm, moral, and ethic that applying in the institution.

Kohlberg $(1980,1985)$ and colleagues (Power, Higgins, Kohlberg, 1989) create moral concept that show "moral climate" or "moral culture" community especially common norm in community. Kohlberg views that context were important to personal moral development were group or community. In the same time Kohlberg theory were critic because he to much intention only to individual thinking and neglect community. Then Kohlberg (Snarey and Samuelson, 2014) and colleagues try to determine another relevant to cognition development and moral development.

Base on Durkheim concept that education integrity are groups, Kohlberg conclude that changes in school moral has big effect to individual moral building. Kohlberg ( snarey samuelson, 2014) say that 
group most helpful to moral development is group that manage by democratic that considerate rights and responsible integration.

Power (2014) defined four indicator for school moral that has high internal consistency. Four indicator if applying in child prison are:

a. Student relation, youth offender relationship with fellow. Interaction with peers had long been theorized to play a significant role in the moral development of youth. Such a moral conception of Justice, reciprocity, and well-being arises from social interaction and social conflict of children with others especially, especially other people who were on the same (Piaget 1932/1965). The main principle is through relationship and interactions with peers build understanding of morality (Piaget, 1932/1965).

b. Students and teacher relationship, youth offender relation with tutor are indicate by youth offender behavior such honoring the tutor, follow lessons in earnest, polite in the association between youth offender, cleanliness, order, the beauty, warmth and security agencies. Child prison has the rules and code of conduct are adhered to as pray when it would begin and end events, honoring the tutor, follow lessons in earnest, polite in the association between youth offender, cleanliness, order, the beauty, warmth and security agencies.

c. School norms, child prison has the rules and code of conduct are adhered to as pray when it would begin and end events, honoring the Builder, follow lessons in earnest, polite in the association between $\mathrm{ABH}$, cleanliness, order, the beauty, warmth and security LPKA.

d. Democratic and educational opportunities, the opportunity involves youth offender democratic means in the whole process of education, youth offender rather than act as objects but as subjects. Freedom for youth offender is covering the freedom of work, develop the potential and argues, the equation of youth offender in education where they existing in these institutions no difference degree or dignity.

Youth offender were adolescent that offend the law that in child prison they got legal awarnes as o good citizen. The citizenship according to Westheimer and Kahne consisting of three types of citizenship: personally responsible, participatory, and justice-oriented (2004a, 2004b in Power 2004:351). According to 18 values that consist to Sistem Pendidikan Nasional (Sisdiknas), so the three value which Westheimer and Kahne has mention were:

1. Democratic ways of thinking, behaving, and act the same rate that the rights and obligations of himself and others. Democratic-oriented relevant to justice because democratic meaning basically oriented to justice both in think, behave and act.

2. Responsibility that is the attitude and behavior of a person to perform the duties and obligations that should he do against oneself, society, environment (natural, social, and cultural) and God Almighty. Responsibility have in common with personally responsible because both shows the execution of the duties and obligations towards yourself

3. Friendly/communicative, actions which show a sense of love to talk, hang out, and working with others. Friendly/communicative relevant to participatory because it shows a collaborative interaction with others. 


\section{Methods}

The correlation research design was employed to investigate character of the youth offender living in child prison in West Sumatra Province, Indonesia and school culture of child prison in West Sumatra Province, Indonesia.

The population of correlation study of community culture and character of 20 youth offender in child prison which has been living in child prison minimum 1 month.

Data for the study was obtained through the administration of copies of structured questionnaire about characteristic of youth offender living in Jail. Nevertheless, the structured questionnaire contained 3 value of character: democratic, responsible, and friendly. The questionnaire was selfadministered after the purpose of the survey and instruction on the questionnaire was explained. The researcher paid series of visits to Jail.

The study employed the purposive and accidental sampling techniques. The purposive sampling technique was used to purposively select only youth offender at least have been living in jail for 1 month and only males.There 32 youth offenders living in Jail but only 20 of them have been living minimum 1 month in child prison in West Sumatera Indonesia.

Data obtained from the administered questionnaire were analysed by pearson. Analysis was carried out using SPSS 17 software for Windows.

\section{Results and Discussion}

Based on data obtained by processing an average of youth offender's perception against the cultural community in Child Prison West Sumatra is 4.00 (Index 5) and the average of the character of the youth offender is 4.125 (index 5). As for the results of the processing of data to see the correlation between the two variables is as follows.

Table 1. Youth Offender's Perception of Community Culture in Chil Prison West Sumatera

\begin{tabular}{|c|c|c|c|}
\hline \multicolumn{4}{|c|}{ Correlations } \\
\hline & & Com. Culture & Character \\
\hline \multirow[t]{3}{*}{ Com. Culture } & Pearson Correlation & 1 & $.512^{*}$ \\
\hline & Sig. (2-tailed) & & .021 \\
\hline & $\mathrm{N}$ & 20 & 20 \\
\hline \multirow[t]{3}{*}{ Character } & Pearson Correlation & $.512^{*}$ & 1 \\
\hline & Sig. (2-tailed) & .021 & \\
\hline & $\mathrm{N}$ & 20 & 20 \\
\hline
\end{tabular}

Description of the data from the table above SPSS processing results shows that there is a significant relationship between the perception of the youth offender against the cultural community that is in child prison West Sumatera with the character of the youth offender. 


\section{Diagram 1. Youth Offender's Perception of Community Culture in Child Prison West Sumatera}

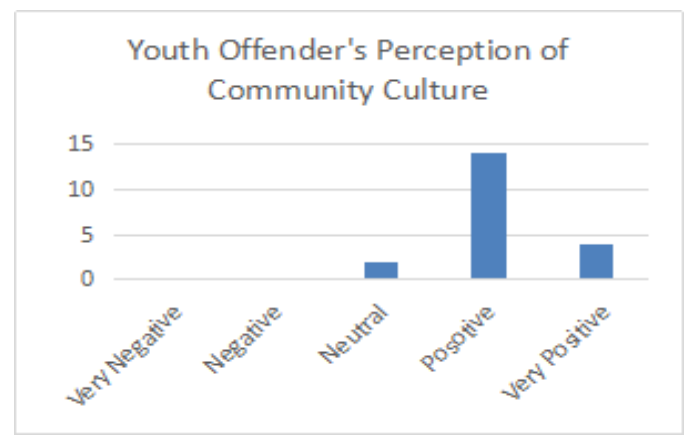

Youth offender's perception of community culture contains four aspect were: youth offender relationship with fellow; youth offender relation with tutor; child prison norm; and democratic and educational opportunities.

\section{Diagram 2. Youth Offender's Character}

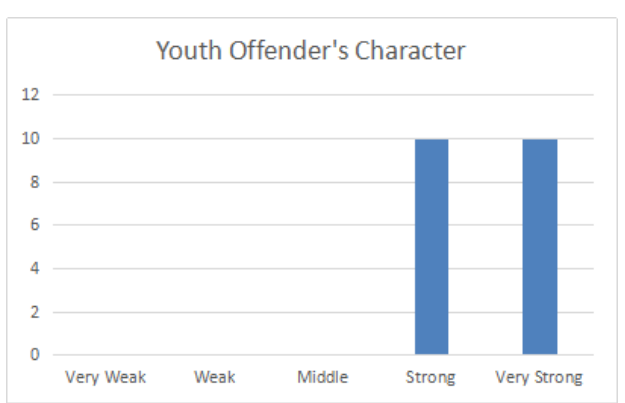

Youth offender's character contains three value are democratic value, responsibility value, and friendly/communicative value. The three value are as follows.

There are relationship between youth offender's perception of community culture and youth offender character with Pearson correlation is 0,512 significant at 0,05 . The community of child prison is a collection of individuals such as youth offenders, tutor, staff, chief of child prison, guard, etc. Community is present because individuals have deficits or deficiencies when apart from other individuals living in larger communities. More than that, the youth offender is actually not born quite self, which means that his existence can grow well and naturally when there is the presence of others.

In a child prison community, each member has an emotional relationship ties called sense of community. Sense of community is an emotional bond between members of the community to share and their needs are met because of this bond. Sarason (1974) defines a sense of community as a perception of: (1) similarity or similarity of youth offender with others, (2) recognition of interdependence in youth offenders, and (3) youth offenders' availability to maintain the interdependence feeling by giving or doing something expected by members of the child prison community. It can be concluded that the sense of community is a youth offender feeling that it is part of a larger group structure, the child prison community.

According to Dalton \& Elias (2001) the sense of community includes four elements: 1) membership (membership), the youth offender feels part of his community, there are five membership attributes; 2) influence (influence), a child prion community has the power/power of mutual influence-influence among members; 3 ) integration (integration) and fulfillment of needs (individuals) joined in child prison community believe that their needs can be met by the existing resources in the community; 4) 
emotional connection (emotional connection) community members (youth offenders) have certain emotional ties related to historical background, time, place and experience together.

Culture as a whole system of thinking, values, morals, and human beliefs that society generates through human interaction with each other and their natural environment (Kemendiknas, 2010: 8). In a child prison community, a community culture is a pattern of behaviors and a way of acting that has been automatically formed into a living part of the community such as youth offenders, tutor, staff, chief of child prison, guard, etc. Basic patterns of behavior and ways of acting or so-called community culture of child prison are the prevailing norms and regulations and policies taken at the local level. It is seen spontaneously in its members (youth offenders, tutor, staff, chief of child prison, guard, etc) in thinking, making decisions and acting in the life of the community everyday.

According to John Dewey (1977 in Power and D' Alessandro, 2014) it is pointless to focus on the development of the child alone regardless of the social context in which they interact. John Dewey realizes that even though a school has no specific program on moral education, each school has its own "school culture" that Dewey defines as a "hidden curriculum". Wren (1999) suggests that the school community's culture of teacher attitudes and behavior is actually more effective in influencing the behavior patterns and ways of thinking of all members of the school community. Likewise with Lickona (2008: 415) which states character building will be much easier to do in an environment where honesty, courtesy, and caring are perceived as prevailing norms. Thus, the community culture of a child prison is an important part of the successful character building of its youth offenders.

\section{Conclusions}

There are relationship between youth offender's perception of community culture and youth offender character. Community culture is present because youth offender have deficits or deficiencies when apart from other individuals living in larger communities. More than that, the youth offender is actually not born quite self, which means that his existence can grow well and naturally when there is the presence of others. In a child prison community, a community culture is a pattern of behaviors and a way of acting that has been automatically formed into a living part of the community such as youth offenders, tutor, staff, chief of child prison, guard, etc. Basic patterns of behavior and ways of acting or so-called community culture of child prison are the prevailing norms and regulations and policies taken at the local level. It is seen spontaneously in its members (youth offenders, tutor, staff, chief of child prison, guard, etc) in thinking, making decisions and acting in the life of the community everyday.

Character building will be much easier to do in an environment where honesty, courtesy, and caring are perceived as prevailing norms. Thus, to building youth offenders' character, child prison as a community must have good community culture such as youth offender good relationship with others, youth offender good relationship with tutor, staff, chief etc, child prison norms that implemented and obey by all of the community members such youth offender, tutor, staff, chief etc and youth offender democratic and educational opportunities.

\section{References}

D'Allessandro, Ann Higgins. (1989). The just community educational program. Theory, research, and educational implication of ethic of care (pp 197-2015). New York: Praeger.

D'Alessandro, Ann.Higgins; Sadh, D. (1997). The Dimensions and Measurement Of School Culture: Understanding School Culture as The Basis For School Reform. International Journal of Educational Research, 27, pp. 553-569.

Doni Koesoema. (2015). Pendidikan Karakter Utuh dan Menyeluruh. Yogyakarta: Kanisius. 
Imam B. \& Derta S.W. Handbook Pendidikan Moral dan Karakter: Pendidikan Moral dalam Tradisi Perkembangan Kognisi: Ide-ide Revolusioner Lawrence Kohlberg. Bandung: Nusamedia

Kementrian Pendidikan Nasional. (2010). Pengembangan Pendidikan Budaya dan Karakter Bangsa. Pedoman Sekolah. Badan Penelitian dan Pengembangan Pusat Kurikulum.

Lickona, Thomas. (2008). Educating for Character. Terjemahan oleh Lita S. Pendidikan Karakter: Panduan Lengkap Mendidik Siswa Menjadi Pintar dan Baik. 2013. Bandung. Nusa Media.

Mahmud, Prof. (2014). Pendidikan Karakter Konsep dan Implementasi. Bandung. Alfabeta.

Power, F.C.; D'Alessandro, Ann Higgins., Kohlberg, Lawrence. (1989). Lawrence Kohlberg's Approach to Moral Education. New York: Columbia University Press.

Power, F.Clark; D'Allessandro, Ann Higgins.(2005). Character, Responsibility, and The Moral Self. South Bend, IN: Universityof Notre Dame Press.

Power, F. Clark. (2014). Building Democratic Community: A Radical Approach to Moral Education. Hoover Press: Damon DP5 HPDAMO070002-14-:212:35:44 rev1 page129-148.

Snarey, John; Samuelson, Peter. (2014). Handbook of Moral and Character Education. Terjemahan oleh Wren, David J. 1999. School Culture: Exploring The Hidden Curriculum. Adolescence, Vol 34, No. 135, Fall. Research Library. San Diego: Libra Publishers, Inc. 